\title{
A Brief Survey of the Smuggling of Fissile Material: An Embryonic \\ Phenomena with a Terrifying Future \\ in the European Community
}

\section{INTRODUCTION}

Following the bombings of Hiroshima and Nagasaki many feared that nuclear weapons technology would spread rapidly throughout the world. ${ }^{1}$ However, this fear has not come to fruition. Since 1945, about one nation has "crossed the nuclear threshold every five years." During the Cold War, the widescale development and use of nuclear weaponry was largely retarded by the United States and the former Soviet Union. These two Cold War adversaries utilized atomic weaponry ${ }^{3}$ in order to arrest each other's aggressiont and influence their feeble client States rather than to effectuate offensive objectives. ${ }^{5}$

Countries of strategic importance to either the Soviet Union or the United States were placed under the auspices of their mentor's nuclear umbrella. ${ }^{6}$ Relying on this umbrella of Armageddon, non-nuclear states typically did not feel the need, nor were they permitted, to develop their own nuclear weapons programs. $^{7}$ This highly structured superpower stand off, coupled with the inescapable terror of nuclear war, stunted the use of nuclear weaponry.

With the collapse of the Soviet Union and the concomitant termination of the Cold War, the bipolar structure of the arms race has been translated into a much more complex equation. ${ }^{8}$ As the former Soviet Union and the United States

1. President John F. Kennedy's prediction, in the early 1960 's, that over 20 nations would have nuclear weapons capacity by the 1970's. David Albright \& Kevin O'Neill, Jury-Rigged, But Working, BULLETIN ATOMIC SCIENTISTS, Jan.-Feb. 1995, at 20.

2. Id.

3. See Barry Kellman, Bridling the International Trade of Catastrophic Weaponry, 43 AM. U. L. REV. 755, 759 (1994). An atomic bomb is composed of a core of fissile material-a minimum of either eight kilograms of plutonium or 25 kilograms of uranium-surrounded by explosives. When the explosives are detonated, the core is imploded, and the fissionable material instantly achieves critical mass, causing a sustained chain reaction that releases vast quantities of energy. Id.

4. See Samuel F. Wells Jr., Nuclear Weapons and European Security During the Cold War, 16 Diplomatic History 278,280 (Spring 1992).

5. See George H. Quester \& Victor A. Utgoff, Deterrence and Proliferation, THE WASHINGTON QUARTERLY (1993) available in LEXIS, Nexis Library, WASHQR File. People are generally "more impressed by what nuclear weapons can do to cities than by what such weapons might accomplish to reverse the military outcome on potential battlefields." Id.

6. William R. Youngblood, Book Note, 9 EMORY INT'L L. REV. 329, 329 (1995) (reviewing Peter Van Ham, Managing Non-Proliferation Regimes IN THE 1990'S: POWER, POLITICS, AND POLICIES (1994)).

7. Id; see also William C. Potter, U.S.-Soviet Cooperative Measures for Nonproliferation, in THE NUCLEAR SUPPLIERS AND NONPROLIFERATION 1 (Rodney W. Jones et al. eds., 1985).

8. Youngblood, supra note 6, at 329-30. 
reduce their weapons arsenals, ${ }^{9}$ and become less involved in maintaining stability along the former Cold War front, other countries are increasing their efforts to develop nuclear weapons as a means of self defense. ${ }^{10}$ As countries scrambled to fill the vacuum of military power, heretofore comatose antagonisms have resurfaced, ${ }^{11}$ thus, placing a premium on the development of a modern military. Hence, the threat that nuclear weapons will be procured by nations previously bereft of such weapons has matured. ${ }^{12}$

Countries often acquire nuclear weapons in order to accrue prestige and to solve real or perceived security threats. ${ }^{13}$ A nation languishing in a long-term affray could radically transform the scope of their confrontation by acquiring nuclear weapons. The procurement of nuclear weapons may also be attractive to a nation facing superior conventional forces or suffering from a perceived identity crisis. ${ }^{14}$ A likely corollary to a nation acquiring nuclear weapons is for its adversary to do likewise. ${ }^{15}$

9. Wolfgang K.H. Panofsky, Safeguarding the Ingredients for Making Nuclear Weapons, 10 IsSUES SCIENCE \& TECHNOLOGY 67 (Spring 1994).

10. Youngblood, supra note 6, at 337. The desire for a non-nuclear state to obtain such weapons is directly proportional to the regional threat. One example of this regional tension is the case of India and Pakistan. India, seeking to increase its security and international prestige, began developing nuclear weapons and, in 1974, conducted its first nuclear test. Pakistan, feeling threatened by India's nuclear program, began its quest for nuclear weapons. Politicians publicly said that if India had nuclear weapons, the people of Pakistan "would eat grass" until they had nuclear weapons of their own. Id. at 337. This pattem of distrust and one-upsmanship is repeated in the Korean peninsula and the tensions between Israel and its Arab neighbors. Nature teaches us that for small creatures having a very deadly bite is an effective means of survival, consider Israel for example. Id. at 340.

11. In response to the Republic of Slovenia and the Republic of Croatia declaring independence from the Federation of the Republics of Yugoslavia in 1991, the Serbian led Yugoslavia People's Army invaded Slovenia. The ensuing battes, systematic rape of women, and "ethnic cleansing" demonstrates such hatreds. See A Whirlwind of Hatreds: How the Balkans Broke Up, N. Y. TIMES, Feb. 14, 1993 at E5, available in LEXIS, Nexis Library, NYT File.

12. See Brad Roberts, 1995 and the End of the Post-Cold War Era, THE WASHINGTON QUARTERLY (1995) available in LEXIS, Nexis Library, WASHQR File. By the Year 2000, it is believed that forty countries will have the ability to produce nuclear weapons. Id.

13. FRANK BARNABY, THE ROLE AND CONTROL OF WEAPONS IN THE 1990's 116 (1992); SEE ALSO GEORGE H. QUESTER \& VICTOR A. UTGOFF, TOWARD AN INTERNATIONAL NUCLEAR SECURITY POLICY, THE WASHINGTON QUARTERLY (1994) available in LEXIS, Nexis Library, WASHQR File.

14. For example, Israel, India, and Pakistan developed nuclear capabilities because each perceived a regional threat to its security as well as a need to enhance its overall military stature. See LAWRENCE SCHEINMAN, THE INTERNATIONAL ATOMIC ENERGY AGENCY AND WORLD NUCLEAR ORDER 4-6 (1987).

15. Science and Technology: Plutonium, Uranium and Pandemonium, ECONOMIST, June 5, 1993, at 98 [hereinafter Plutonium]; Quester \& Utgoff, supra note 13. "Iraq's nuclear program was motivated by its desire to end Israel's nuclear monopoly in the Middle East. Had Iraq's nuclear program not been severely damaged as a result of allied bombing, Iran and Syria and 
Since developing nuclear weapons is difficult, a country must either be extremely weal thy or fanatical in order to cultivate their own nuclear weapons. ${ }^{16}$ Those nations inept at indigenously developing nuclear technology may resort to the smuggling of nuclear material and the importation of nuclear expertise in order to circumvent existing prohibitions in the marketing of nuclear weapons. With the existing uncertainty in Russia and the Commonwealth of Independent States (CIS), the concern over the smuggling of fissile weaponry is particularly acute. ${ }^{17}$. In fact, R. James Woolsey, former Director of the United States Central Intelligence Agency (CIA), has stated that the potential for trafficking nuclear weapons is "fueled by a combination of declining morale among Russian security services and workers at nuclear research and production facilities, and customers such as Iran who are eager to shorten their timetable for development of nuclear weapons." 18

perhaps even Egypt would have had strong motivations to move ahead themselves. "BARNABY, supra note 13 , at 117.

16. Plutonium, supra note 15 , at 98 .

17. As, a consequence of the collapse of the Soviet totalitarian command and control society, a vast potential supermarket of nuclear weapons and fissile material is becoming increasingly accessible. The collapse of the Soviet Union and the subsequent decay of the custodial system guarding the Soviet nuclear legacy has eliminated this proliferation chokepoint, since states and possibly even sub-state groups can now buy or steal what they previously had to produce on their own. This central fact has transformed the nature of the proliferation problem for ... the rest of the world.

Avoiding Nuclear Anarchy: Containing the Threat of Loose Russian Nuclear Weapons and Weapons-Usable Nuclear Materials, , Testimony before the Senate Foreign Relations Committee: Subcommittee on Foreign Relations, Federal Document Clearing House Political Transcripts, Aug. 23, 1995, available in LEXIS, Nexis library, HILLPR File [hereinafter Nuclear Anarchy] (Graham T. Allison et al, Center for Science and International Affairs, Kennedy School of Government, Harvard University). David Osias, a strategic programs analyst for the Central Intelligence Agency stated: "Our concem about possible loss of weapons-usable nuclear material is increased by our recognition that the Russians may not know either who has all their material or where it is located. The fact that some material has made it out increases the likelihood that other material will also." A Six-Pack of Nuclear Bombs, To Go, CHI. TRIB., Aug. 28, 1995, at 14, available in WESTLAW 1995 WL 6240410; Arthur Allen, Operation Hades: German Police Stings Create Market for Nuclear Smuggling, OTTAWA CITIZEN, Sept. 2, 1995, at B3, available in WESTLAW 1995 WL 4324041; Nuclear Smuggling Continues Los Alamos Scientist Cites Blackmail Threat, DENv. POST, Aug. 25, 1995, at B03, available in West. AW 1995 WL 6582149; Bill Schackner, More and More, Nuclear Fuels are Being Stolen, PITTSBURGH POSTGAZETTE, July 16, 1995, available in WESTLAW, 1995 WL 3393553.

18. Prepared Statement of R. James Woolsey, Director of Central Intelligence before the Senate Select Committee on Intelligence World Threat Assessment Brief, Federal News Service, Jan. 10, 1995, available in WESTLAW, 1995 WL 6620595. 
In addition to the five declared nuclear powers, ${ }^{19}$ at least a half-dozen nations from the Middle East, the Indian subcontinent, and the Korean Peninsula, as well as some terrorist groups are actively pursuing nuclear weapons capacity, some of whom presumably already possess this technology. ${ }^{20}$ Terrorist groups, previously proscribed from acquiring nuclear technology, could conceivably penetrate this arena. ${ }^{21}$ If this occurs, they could threaten nuclear holocaust to extort extravagant demands. ${ }^{22}$ Terrorists do not need the precision and polish of a high-yield weapon. Instead, a crude, low-yield bomb could serve their purpose, demolishing a large portion of a city. ${ }^{23}$

19. Treaty on the Non-Proliferation of Nuclear Weapons, opened for signature July 1 , 1968, art. IX, I 3, 21 U.S.T. 483, 492-93, 729 U.N.T.S. 161, 174 [hereinafter NPT]. For the purposes of the Treaty, a nuclear-weapon State was one which had manufactured and exploded a nuclear weapon or other nuclear explosive device prior to January 1, 1967. Five such states existed: China, France, Great Britain, the Soviet Union, and the United States. Presently, however, numerous other states either have nuclear weapons or the technology; they include: Israel, India, Pakistan, South Africa, North Korea, and Japan. See Global View: Secret Nuclear Weapons Development Programs (CNN television broadcast, Sept. 10, 1994) (transcript available in LEXIS, Nexis Library, CNN File) [hereinafter Global View] (interview with David Kay, chief inspector in Iraq for the International Atomic Energy Agency).

20. Global View, supra note 19.

21. Allison, supra note 17.

Obviously, the random lone terrorist will not be able to fabricate a nuclear weapon. Clearly, many groups of terrorists (or criminals) will lack the technical wherewithal to make nuclear weapons. The point here is not that the entire universe of criminal weapons. The point is that some terrorist groups will likely be able to do so. After all, some groups that employ terror encompass large numbers of people, many of them educated; they are well organized and highly motivated; they can have access to substantial financial resources; and they may have the support of states or groups within states. Given time and fissile material, such a group could be Id. capable of producing a nuclear weapon-especially if it had a little help.

There have been no cases of a rogue state or terrorists using nuclear weapons. The sarin gas attack in Tokyo comes the closest to a terrorist attack using a weapon of mass destruction. This case may have relevance to nuclear terrorism to the extent that the cult had acquired a sophisticated laboratory and developed the capability to manufacture and stockpile a sizable quantity of and engineers.

Hearings on Nuclear Smuggling in Russia and Threat of Nuclear Terrorism. Senate Foreign Relations Committee, European Affairs Subcommittee, Federal Document Clearing House Political Transcripts, Aug. 23, 1995, available in LEXIS, Nexis Library, HLLPR File [hereinafter Hearings] (testimony of Dr. Thomas Cochran).

22. Plutonium, supra note 15, at 98; Jennifer Lin, New Kind of $N$-peril emerging Rogue Nations, Terror Groups could Acquire Deadly Materials, SAN DiEgo UNion TrIBUNE, April 17, 1995, at A I, available in WESTLAW, 1995 WL 5714041.

23. Plutonium, supra note 15 , at 99.

If terrorists who attacked the 110-story World Trade Center in 1993, or . . . the Federal Office Building in Oklahoma City [in April 1994] ... had used the same mini-van that they drove ... but carried not the chemical-based explosives that they used but rather a weapon that [was 30 pounds of HEU] ... [t] hey could have 
As nuclear capabilities spread, technological constraints on proliferation weaken. Preventing the proliferation of nuclear arms has become far more important than preventing or preparing for direct nuclear conflict. Controlling proliferation will necessitate dealing with technical, institutional, and political difficulties. ${ }^{24}$ Moreover, increasing sources of supply undermine international control efforts and exasperate proliferators vulnerability to possible consequences. This note will examine what can be done to curtail the potentially devastating result of fissile material smuggling, holocaust. Part I will examine the perils of smuggling and how this is aggravated where nuclear weapons are concerned. Part II will investigate the applicable aspects of the Nuclear NonProliferation Treaty. Part III will examine the International Atomic Agency and demonstrate how it is currently incapable of dealing with smuggling. Part IV will examine the policing mechanisms in place in Europe, i.e., Interpol and Europol, and determine how they may be strengthened to deal with this embryonic disaster. Part $V$ will offer recommendations to curtail the smuggling of fissile material.

\section{The PRoBlems WITH SMUGgLING IN THE EUROPEAN COMMUNITY AND RUSSIA}

\section{A. Fissile Material}

The smuggling of fissile material from the former Soviet Union is suspicioned by the West as possibly the most intolerable "wave" of organized crime sweeping not only Russia but all of the former Eastern Bloc countries. ${ }^{25}$ The authoritarian mechanisms that formerly safeguarded Soviet nuclear material can no longer be assured; ${ }^{26}$ hence, the potential for the smuggling of nuclear commodities exists. For example, attempts to smuggle fissile material into Germany has expanded in recent years. According to the Bundesnachrichtendienst (BND), a German police agency, attempts have grown from forty-one in 1991, 158 in 1992, 241 in 1993, to 267 in 1994. ${ }^{27}$ Many of

created an explosion of 10,000 to 20,000 tons of TNT, which would have demolished an area of about three square miles.

Hearings, supra note 21 (testimony of Dr. Graham Allison).

24. Panofsky, supra note 9.

25. Giovanni Facchini, Smuggling of Nuclear Material from Eastern Europe Alarms Experts, DeUTSCHE Presse-AGENTUR, July 5, 1994, available in LEXIS, Nexis Library, International File.

26. Bumus M. Camahan, Nuclear Smuggling as an International Crime, 28 AKRON L. REV. 417,418 (1995). The Soviet safeguarding system relied in large part upon psychology. The Soviets were confident in its control over its people hence any safeguards that were put in to place focused on threats from outside of the Soviet Union. Plutonium, supra note 15, at 99.

27. Tyler Marshall, European Nations Combine to Combat Crime, Los ANGELEs TIMES, Sept. 9, 1994. See also Ninety Radioactive Smugglings Found in Germany in First Half Year, XINHAU NEWS AGENCY, Sept. 14, 1994, available in LEXIS, Nexis Library, International File. 
these reported instances have been frauds or have involved material that in no way could be used to develop nuclear weapons. In fact, "since the fall of 1992, there have [only] been five serious cases of diversion of weapons-usable fissile material" the rest have either been hoaxes or have involved material that is not weapons-grade..$^{28}$ Nevertheless, "[t]he fact that a large fraction of the reports of nuclear smuggling have been scams involving material with no relevance to nuclear weapons, should not blind us to the seriousness of the smaller but still significant number of cases that have involved nuclear weapons materials." 29

"The fall of the Iron Curtain and the loosening of internal borders within the (European) Union has resulted in a freer and more deregulated environment. which has created the perfect breeding ground for organized crime syndicates and their illicit activities." ${ }^{30}$ Evidence exists that organized crime syndicates, or an "Atomic Mafia," have attempted to access Russia's 33,000 nuclear warheads ${ }^{31}$ in order to peddle them for exorbitant sums abroad. ${ }^{32}$ The fear of a "Russian

28. Hearings, supra note 21 (testimony of Dr. Thomas Cochran). An example of a serious case of smuggling occured in November 1994. There, Czech authorities found six pounds of HEU in the back seat of an automobile parked on a side street. In addition, Russian documents were found with the fissile material. A Czech nuclear scientist, a Russian and a Belarussian were arrested in connection with the seizure. Allison, supra note 17.

29. Id. (testimony of Dr. John Holdren). Even though many of the alleged incidents of smuggling of fissile material turn out to be untrue or unproven or involve anything "remotely 'nuclear' - such as radioactive material used for medicinal purposes- . . the available facts are grounds for grave concem, for at least five reasons." Allison, supra note 17.

First, the large number of real or fraudulent efforts to sell things nuclear suggests a widespread appreciation within Russia that such material have market value. Second, these facts indicate that there is considerable effort within Russia to fill the supply side of an emerging, if not formed, nuclear black market. Third, the fact that there is a large number of failed or false attempts to move nuclear materials across international borders is less important than the reality that even a tiny number of successes in transferring nuclear weapons or weapons quantities of fissile material would have very damaging, if not disastrous, consequences. Fourth, it is unlikely that every attempt at nuclear smuggling is detected and reported; by definition, successful transactions on the black markets are covert and unnoticed. Finally, and perhaps most tellingly, buried in the large number of claimed cases are a small number of very serious, unchallenged, and unambiguously dangerous incidents.

ld.

30. Joel S. Solomon, Forming a More Secure Union: The Growing Problem of Organized Crime in Europe as a Challenge to National Sovereignty, 13 DICK. J. INT'L L. 623, 623 (1995).

31. Russia has so many weapons due to the fact that fresh plutonium slowly undergoes radioactive decay, making it unpredictable in warheads. The United States solves this problem by recycling old material, and chemically extracting impurities. As a rule, the Soviet Union did not refresh its plutonium. Aging weapons simply were placed in reserve, replaced by warheads full of fresh plutonium. Plutonium, supra note 15, at 99.

32. See David Morelli, Russian Isotopes Recovered: Stolen Non-radioactive Elements Seized by Authorities, WINDSOR STAR, Feb. 9, 1995, at A4, available in WESTLAW, 1995 WL 
Mafia" extends to most countries. ${ }^{33}$ The United States Federal Bureau Of Investigation (FBI) is "gravely concerned [that] Russian organized crime members may have already obtained, or will obtain, the capacity to steal nuclear weapons." 34 According to various estimates, organized crime controls about seventy to eighty percent of private business in Russia. ${ }^{35}$ James Woolsey has claimed that about 5,700 organized crime syndicates operate in Russia, 200 of which have international affiliations. ${ }^{36}$

Conservative estimates place Russian stockpiles of weapons-grade plutonium at approximately 150 tons and weapons-grade uranium close to 900 tons. ${ }^{37}$ Since neither plutonium nor the applicable uranium (U235 which is often referred to as Highly Enriched Uranium or HEU) exists naturally, the primary difficulty in producing nuclear weapons lies in obtaining sufficient quantities of the refined material. ${ }^{38}$ The sheer volume of weapons grade material engenders the possibility that some material will escape the current control mechanisms. ${ }^{39}$

3612061; Eric Geiger, Austria Feels Chill of Booming Russian Mafia, S.F. CHRonıcLE, Jan. 22, 1995, at G23, available in WESTLAW, 1995 WL 5266665.

33. Russian organized crime members include not only petty criminals, but also former security and intelligence agents from the now defunct KGB, former Communist Party officials and military officers. Russian Crime a Global Threat, SAN ANTONIO EXPREss-NEWs, June 25, 1995, available in WESTLAW, 1995 WL 5566012; Ricardo Chavira, U.S. Tackles Global Spread of Russian Mob: Underworld's Threat to National Security Foster Cooperation among Agencies, Series: International Crime, DALLAS MORNING NEWs, June 4, 1995, at 1A, available in WESTLAW, 1995 WL 9040347.

34. Global View, supra note 19, statement by Louis Freeh, FBI Director.

35. "Approximately 40,000 Russian business and industrial enterprises are controlled by organized crime. Their combined turnover, over ten billion dollars, is higher than the gross domestic product of many members of the United Nations." Ariel Cohen, The Mob and Russia, SAN DiEgo Union TriB., Sept. 10, 1995, at G4. See also, Celestine Bohlen, Graft and Gangsterism in Russia Blight the Entrepreneurial Spirit, N.Y. TuMES, Jan. 28, 1994 at Al, available in LEXIS, Nexis Library, NYT File.

36. Woolsey, supra note 18.

37. Europe: The Plutonium Racket, EoonomIST, Aug. 20, 1994, at 39 [hereinafter Racket].

38. Panofsky, supra note 9.

Controlling proliferation will necessitate dealing with technical, institutional, and political difficulties. The dominant technical difficulty is limiting access to fissionable material-the plutonium or highly enriched uranium (HEU) that can be used to make a nuclear weapon. Well over 20 percent of HEU is in the form of the fissionable isotope uranium 235. Natural uranium contains only 0.7 percent uranium 235; the balance is uranium 238. Plutonium does not occur in nature; it is produced inside a nuclear reactor, through neutron capture by uranium 238 , followed by beta decay.

Id.

39. Id:; David Perlman, Piles of Plutonium Leftovers Grow as Bombs are Taken Apart, S.F. CHronicle, Apr. 12, 1995, available in WESTLAW, 1995 WL 5277324. 
Only a fraction of these huge stocks in the wrong hands would create havoc. ${ }^{40}$ After efforts to cover up accidents and due to the lax security at its nuclear arsenals, ${ }^{41}$ some Russian experts have reluctantly admitted that some superfluous nuclear warheads may not be adequately secured. ${ }^{42}$

Due to the disarmament treaties between the United States and the former Soviet Union, roughly six tons of plutonium and thirty tons of HEU are due to be released annually over the next thirteen years. ${ }^{43}$ As weapons are gradually dismantled, the separated plutonium and uranium are either stockpiled or processed ${ }^{44}$ by Minatom, the Russian Ministry of Atomic Energy and principle nuclear custodian. ${ }^{45}$ The U.S. and Russia are engaged in a cooperative effort to control and account for fissile material in order to help ameliorate the logistical quandary of fissile material dismantlement. ${ }^{46}$ Minatom and a private U.S. corporation, the U.S. Enrichment Corporation, have an agreement whereby Enrichment Corporation purchases nuclear material from Minatom which has been reprocessed into a commercially viable product. Enrichment Corporation

40. A crude atom bomb requires a mere $15 \mathrm{~kg}$ of this uranium or five $\mathrm{kg}$ of the plutonium, about the size of a grapefruit. Panofsky, supra note 9. Thomas Cochran, the director of the Natural Resources Defense Council, sought to impress this point during a Capital Hill briefing. He had a six pack of Coca Cola cans filled with 15 pounds of uranium. The uranium was not weapons usable. If the fifteen pounds (or 6.8 kilograms) were plutonium it would have represented more plutonium than was used on Nagasaki during World War II.

A country like the United States or Russia with very sophisticated capabilities could make small nuclear weapons with [close to] three to five kilograms of [HEU] or [approximately] one kilogram of plutonium. And if you start doubling that amount, you can do the same thing with greater ease, with less sophistication in the design.

Hearings, supra note 21 (testimony of Dr. Thomas Cochran). According to Dr. Cochran's estimates, a Middle Eastern country could take the material that has been smuggled to date and produce a low-yield nuclear weapon using technology used in the United States and Russia in the 1950's. Id; see also Global View, supra note 11.

41. Larry Thomson, Yeltsin's Nuclear Report Reveals Problems, Buffalo News, Aug. 7 , 1995, at A3, available in WESTLAW, 1995 WL 5493568.

42. Plutonium, supra note 15, at 98 . Alexei Lebedev of the Russian Atomic Energy Ministry openly states that there is no firm assurance that nuclear weapons have been stored in secured bcations. Bettina Vestring, German Police Smuggled Radioactive Material, REUTERS, September 12, 1994, available in LEXIS, Nexis Library, International File.

In Russia, growing concern about the security at nuclear installations has prompted the formation of a special battalion of troops to combat possible nuclear terrorism and the smuggling of nuclear materials. Andrei Ivanov, Russia: "Hooligan" Hunting Nuclear Weapons Face Special Amy Unit, INTER Press SERVICE, May 1, 1995, available in WESTLAW, 1995 WL 2260776.

43. PJutonium, supra note 15 , at 98 .

44. $l d$. at 99.

45. Id.

46. State Department Briefing, Mike McCurry, Aug. 17, 1994, available in LEXIS, Nexis Library, DSTATE File. 
then peddles the material to civilian entities. ${ }^{47}$ The U.S. has offered Russia up to $\$ 30$ million to help account for the fissile material not yet dismantled and improve the security of the weapons. ${ }^{48}$ The U.S. hopes to install temporary safeguards with the goal of establishing a more permanent and protective system patterned after the U.S. Nuclear Regulatory Commission. ${ }^{49}$ Under that system fissile material is counted to within four-tenths of a gram, a stringent technical control regime costing the U.S. about $\$ 700$ million a year to operate..$^{50}$

The CIS and Russia have been consistent in their denial that any nuclear material has escaped their territories. ${ }^{51}$ Russian officials charge that the reports of smuggling of fissile material is a Westem ploy aimed at gaining control over Russian nuclear weapons. ${ }^{52}$ They claim that such campaigns have been launched to prevent the presence of CIS enriched uranium, isotopes, and heat-releasing elements in the world market. ${ }^{53}$ Alexander Mikhailov, an official of the Russian Federal Counter-Espionage Service (FSK), asserts that, "[a]ttempts to blame Russia for being unable to control the non-proliferation of its nuclear weapons, technologies and materials are politically-motivated"s4 and that the "accusations of Russian laxity [are] part of a campaign to prepare public opinion "for the idea of implementing political control over Russian nuclear weapons." "ss Germany, for instance, is believed to have attempted to dramatize the situation with hopes of obtaining full disclosure of all nuclear inventories. ${ }^{56}$ In fact, some believe that many of these incidents have been prompted by German officials ${ }^{57}$ by their

47. Id.

48. Id.

49. Id.

50. Global View, supra note 19.

51. Christine Spolar, Slovakian Holds 9 in Uraniwn Plot; Car From Ukraine Said to Bring in 100 pounds of Nuclear Material, WASHINGTON POST, April 22, 1995, at A25, available in WESTLAW, 1995 WL 2089976.

52. Russian Cites Western Plot in Nuke Smuggling Reports, AgEncE France Presse, August 16, 1994, available in LEXIS, Nexis Library, AFP File.

53. $I d$

54. Id.

55. Id.

56. Sedthe Press on Nuclear Smuggling and the Intelligence Service, WEEK IN GERMANY, April 21, 1995, available in WESTLAW, 1995 WL 2272717. Germany does not have any nuclear weapons.

57. Trial Puts Spotlight on Smuggled Russian Plutonium, CAlgary Herald, May 16, 1995, at A5, available in WESTLAW, 1995 WL 7301384; German Intelligence Accused of Cooking up Plutonium Plot, ARzONA REPUBLIC, May 12, 1995, at A8, available in WESTLAW, 1995 WL 2792532; Plufonium Bust Faked, MonTreal GAZETTE, April 20, 1995, at B1, available in WESTLAW, 1995 WL 6957333.

On August 10,1994, three men were arrested in Munich, Germany, when German police seized a suitcase with about 400 grams of highly enriched plutonium. These arrests came about after an underoover operation involving German intelligence agents. Gcorgi Saurov, a spokcsman for Russia's Nuclear Energy Ministry supported a report that a German intelligence agency 
offering of huge payments in sting operations. ${ }^{58}$

Regardless of Germany's motives or Russia's claims, concern that fissile material may eventually find its way into the wrong hands is legitimate. In fact, the Ukraine has previously suspended the transfer of nuclear weapons to Russia due to the "political instability and confusion" that has existed within the Russian Federation. ${ }^{39}$ The Ukraine's concern was that the missiles being returned to Russia were not being destroyed, but actually falling into unfriendly hands. ${ }^{60}$ This concern may be credible considering additional reports from Kazakhstan stating the possibility that the republic has had three or four weapons disappear. ${ }^{61}$

The absence of centralized control in Russia hinders the fight against smuggling. A paradigm of this acute problem exists in Central Asia. There, smuggling has been developed over the centuries into a highly skilled craft to the extent that even when the Soviet army and KGB controlled the border areas, local communities conducted trade with non-Soviet states. ${ }^{62}$ In fact, smuggling via Armenia or Afghanistan has become a highly successful enterprise with little chance of detection. ${ }^{63}$ This skill in smuggling coupled with the Muslim brotherhood of southem border republics and the nearby states that crave nuclear technology, i.e., Iran and Iraq, could conceivably lead to the border republics aligning themselves with their fellow Muslims rather than the rest of the CIS and Russia ${ }^{64}$ If such alliances do coalesce, the proliferation of former Soviet fissile materials stationed in the republics to punitive states is plausible.

\section{B. Nuclear Expertise}

In the former Soviet Union, as many as 100,000 scientists, engineers and technicians developed and cultivated the largest nuclear weapons arsenal in the world. ${ }^{65}$ Two to three thousand scientists were involved in plutonium production and uranium enrichment activities-two of the most sensitive areas in nuclear

shipped 12.8 ounces of weapons-grade plutonium to Moscow and back so it could be seized on its arrival. Spolar, supra note 51.

58. Arthur Allen, Spy Scandal in Germany, Dayton Dally NEws, June 24, 1995, at 5 A, available in WESTLAW, 1995 WL 8951370.

59. Ukraine Halts Transfer to Russia of Nuclear Arms, REUTERS, Mar. 12, 1992, available in LEXIS, Nexis Library, Intemational File [hereinafter Ukraine]; see generally Victor Batiouk, Ukraine's Non-Nuclear Option, UNIDR, United Nations Institute for Disarmament Research (1992).

60. Ukraine, supra note 59.

61. Plutonium, supra note 15 , at 98.

62. Igor Levin, Where Have all the Weapons Gone? The Commonwealth of Independent States' Struggle to Stop the Proliferation of Nuclear Weapons and the New Role of the International Atomic Energy Agency, 24 N. Y. U. J. INT'L L. \& PoL. 957, 966 (1992).

63. Racket, supra note 37 , at 40.

64. Levin, supra note 62, at 966.

65. SCHEINMAN, supra note 14, at 148. 
weapons production. ${ }^{66}$ With the fall of the Soviet Union, programs for the development of nuclear weapons have been dramatically abated. Testing grounds have been shut down while production at several major nuclear facilities has terminated. ${ }^{67}$

Due to the acrimonious fiscal realities existing in the former Soviet Union, despondent scientists emigrating to punitive states as nuclear mercenaries is a grave concern. ${ }^{68}$ This "brain drain ${ }^{6 \theta}$ extends beyond nuclear mercenarie?, inclusive in the problem are those scientists seeking legitimate employment outside the former Soviet Union. ${ }^{11}$ Unsophisticated in the world arena, a scientist believing she is being employed on a civilian nuclear power project may inadvertently supply general information and expertise useful for weapons development. In fact, Iraq set up front companies in Western Europe in order to recruit unsuspecting Commonwealth scientists who would not otherwise consider laboring for rogue states like Iran, Iraq, or Libya ${ }^{72}$

The concern over the smuggling of fissile material and expertise has merit regardless of whether Russian scientists are insulted by these accusations. ${ }^{73}$

66. Potter, supra note 7, at 4; See Youngblood, supra note 6, at 339.

67. Worries Express Over Export of Nuclear Expertise, The British Broadcasting Corporation Summary of World Broadcasts, Jan. 15, 1992, available in LEXIS, Nexis Library, International File [hereinafter Nuclear Expertise].

68. Robert Lee Hotz, Cold War Foes Forge Warm Ties What Once Was Called Treason is Now Encouraged by the U.S. and Russia, L.A. TIMES, June 23, 1995, at 1, available in WESTLAW, 1995 WL 2059058; Lin, supra note 22.

69. The term "Brain Drain" was first used to describe the emigration of former Nazi weapons scientist to the United States after World War II. Another significant episode of "Brain Drain" occurred during the early 1950's when hundreds of high level British radar and communications scientists emigrated to the United States and Canada in response to the worsening economic conditions in the United Kingdom. See Generally Adam Treiger, Note, Plugging the Russian Brain Drain: Criminalizing Nuclear Expertise, 82 GEO. L.J. 237 (1993).

70. The scope of the brain drain is demonstrated on the Internet. There, scientists are able to interact with little chance of detection. The Internet does not recognize national borders and it is not subject to inspection by the International Atomic Energy Agency. In addition, with the encryption programs widely available, the United States National Security Agency or the former KGB are hard pressed to crack private E-mail. See Alan Cooperman \& Kyrall Belianinov, Moonlighting by Modem in Russia, Hard-Up Scientists Sell Their Skills Abroad, U.S. NEWs \& WORLD REPORT, April 17, 1995, at 45, available in WESTLAW, 1995 WL 3113667.

71. There is historical precedence for the exodus of skilled scientists, as evidenced by the large number of German rocket scientists who came to the United States after World War II. Youngblood, supra note 6, at 339.

72. Treiger, supra note 69, at 239 (Anns Trade and Proliferation in the Middle East: Hearing Before the Subcommittee on Technology and National Security of the Joint Economic Comm., 102d Cong., 2nd Sess., pt. 2, at 25 (1992)(statement of William C. Potter, Director of the Center for Russian and Soviet Studies)).

73. Sergei Kapitza, a physics professor at the Academy of Sciences in Moscow explains:

This fear is based on some strange and irrational assumption and stereotypes . .

. . To single out nuclear scientists from Russia-however difficult their current 
Russian nuclear scientists are no more amoral than their Western counterparts and are similarly horrified of nuclear proliferation. Nevertheless, many Russian scientists, formerly unfamiliar with fiscal anxieties, now must survive on meager gratuities. ${ }^{74}$ Incentives offered by a few nations are sufficient to convince even the most idealistic scientist to stray from the path of nonproliferation when confronted with fiscal ruin. ${ }^{75}$

In an attempt to ameliorate the harsh economic situation for the once high level physicists and engineers, Russia has implemented a conversion program. ${ }^{76}$ while the European Community, the United States, and Japan have pledged to fund two nuclear research centers in the CIS. ${ }^{77}$ The Russian program is an attempt to convert many of the weapons producing industries into other enterprises such as automobiles or electronics. Unfortunately, the program has not been overly successful, as many of the former elite scientists are now relegated to designing "new kinds of iceboxes and . . . baby buggies . . . ."78 With these menial vocations, most salaries have deteriorated. ${ }^{79}$ That some of these scientists may become discouraged at the lack of use of their extensive expertise and training is self-evident.

The joint plan by the European Union, United States, Japan and the Russian Federation has also been developed in an effort to help Russian military experts channel their talents towards peaceful scientific and industrial activities. ${ }^{80}$ The International Science and Technology Centre's (ISTC) objective is to "give Russian and other CIS weapons scientists and engineers opportunities to redirect

position-is an expression of distrust, if not a direct insult, to that community. Are we really to consider a nuclear bomb maker in the same category as a paid assassin?

Sergei Kapitza, Debunking the Latest Red Scare, HARPERS MAG., July 1992, at 15-16, (quoting Soviet Scientists: Low Pay, No Pay, Now Insults, BULlETIN ATOMIC SCIENTISTS, May 1992).

74. See Iraq Said to Hire 50 Soviet Nuke Scientists, THE REUTER LIBRARY REPORT, Mar. 3, 1992, available in LEXIS, Nexis Library, International File [hereinafter Iraq]. Some salaries have been reduced to the equivalent of fifty dollars per month and some to as low as twelve dollars per month. In order to better understand the situation fully, the compensation system in the former Soviet Union must be examined. There, nuclear scientists were among the highest paid personnel in the country. Access to goods and services was more important than money, and most were provided with top of the line cars, apartments, health care, ctc. These perks coupled with relatively high salaries show the true compensation allotted to the scientists. The dwindling perks in addition to the meager salaries allotted to the scientists evidences their plight. Id.

75. Stephanie G. Neuman, Controlling the Arms Trade: Idealistic Dream or Realpolitik?, THE WASHINGTON QUARTERLY (1993), available in LEXIS, Nexis Library, WASHQR File.

76. Nuclear Expertise, supra note 67.

77. Youngblood, supra note 6, at 339.

78. Nuclear Expertise, supra note 67.

79. Iraq, supra note 74.

80. Moscow Science and Technology Centre goes into Operation, Commission of the European Communities, RAPID, Mar. 17, 1994, available in LEXIS, Nexis Library, CURNEWS File [hereinafter Moscow]; see also Youngblood, supra note 6, at 339. 
their talents to peaceful activities, responsive to civil needs, and to promote their integration into the international scientific and industrial communities."81 "To promote the objectives of the ISTC, the signatory Parties will finance, through the Centre, research and development projects by Russian scientists and institutions formerly engaged in military activities." 82 "The cummulat[ive] contributions of the parties will amount to approximately 65 million [dollars] for [the first] two years."

The predicament does not necessarily concentrate within the Russian military establishment, where there is yet to be one confirmed incident from missing material, but with civilian controls. ${ }^{84}$ Laboratory results taken of samples from previous recoiveries confirm this, indicating that the fissile material originates from spent nuclear fuel from nuclear submarines and material for medical purposes produced by research reactors. ${ }^{85}$ Consequently, the initial preventive measures should concentrate on the civilian sector. As the counting of bombs gives rise to the accounting for the material, i.e., dismantlement, the chances that material will disappear during this process are particularly acute.

\section{THE NON-PROLIFERATION OF NUCLEAR WEAPONS TREATY}

The Nuclear Non-Proliferation Treaty (NPT) ${ }^{86}$ is one of the most farreaching legal instruments currently in place to combat the spread of nuclear weapons materials and expertise. ${ }^{87}$ For a quarter of a century, the NPT has been the "touchstone of all international efforts to limit the spread of nuclear weapons." ${ }^{\prime 88}$ With over 170 parties, it is the most widely adhered to arms control agreement in history. ${ }^{89}$

81. Moscow, supra note 80 .

82. Id

83. Id.

84. Neuman, supra note 75 .

85. Id.

86. NPT, supra note 19, at Art. I. The initial NPT was in force in 1970 and was to last 25 years. The NPT was, however, indefinitely prolonged at a conference in New York City in May 1995. Igor Maximov, Nuclear Nonproliferation Treaty Prolonged for Indefinite Time, RussiaN PRESS DIGEST, May 12, 1995, available in WESTLAW, International Library, RPD File.

87. Other treaties or organizations dealing with proliferation of nuclear weapons include: Nuclear Suppliers Group (a cartel comprised of seven main nuclear supplier countries); Coordinating Committee for Multilateral Export Controls (an organization formed in conjunction with the U.S. Mutual Defense Assistance Control Act of 1951) see Cecil Hunt, Cocom and other International Cooperation in Export Control, 675 PRACTICING LAW INSTITUTE/COMM. 295 (1993); the Missile Technology Control Regime (mechanism organized by the G-7 to restrict the export of missile technology); the Chemical Weapons Convention (designed to ban the development, production, and stockpiling of chemical weapons); and the Biological Weapons Convention (set up to ban the development, production, and stockpiling of biological weapons).

88. Lin, supra note 22.

89. See Quester, supra note 5. 
The NPT is concerned with stemming the demand for nuclear weapons. "[It] addresses horizontal proliferation by requiring non-nuclear states to comply with the International Atomic Energy Agency [IAEA] safeguards in order to receive the benefits of nuclear technology for peaceful purposes." "It also addresses vertical proliferation, requiring the nuclear states to pursue in good faith complete nuclear disarmament." ${ }^{11}$ Pursuit of these goals is premised on the fact that the vast majority of nations do not possess nuclear weapons technology and that indigenous development of such technology would be extremely difficult. ${ }^{92}$

Asymmetrical in nature, the NPT's participants have considerably divergent rights and obligations. ${ }^{93}$ The five nuclear weapons states ${ }^{94}$ agree not to export those items necessary for the development of nuclear weapons. ${ }^{95}$ In retum, those non-nuclear weapon countries are allowed to import items necessary for the production of peaceful nuclear power, subject to enforcement by the IAEA. ${ }^{96}$

Articles I and II of the NPT set forth the basic duties of the signatory states. Article I dictates:

Each nuclear-weapon State Party to the Treaty undertakes not to transfer to any recipient whatsoever nuclear weapons or other nuclear explosive devices or control over such weapons or explosive devices directly, or indirectly; and not in any way to assist, encourage, or induce any non-nuclear-weapon State to manufacture or otherwise acquire nuclear weapons or other explosive devices, or control over such weapons or explosive devices. ${ }^{97}$

Article II requires that:

Each non-nuclear weapons State Party to the treaty undertakes not to receive the transfer from any transferor whatsoever of nuclear weapons or other nuclear explosive devices or of control over such weapons or explosive devices directly, or indirectly; not to manufacture or otherwise acquire nuclear weapons or other nuclear explosive devices; and not to seek to receive any assistance in the

90. Youngblood, supra note 6, at 331.

91. Id.

92. See generally NPT, supra note 19, at Arts. I, II.

93. William Epstein \& Paul C. Szasz, Extension of the Nuclear Non-Proliferation Treaty: A Means of Strengthening the Treaty, 33 VA. J. INT'L L. 735, 736 (1993).

94. The treaty divides its signators into two groups: the five declared nuclear weapons states, each of which tested a nuclear device prior to 1967 and all others. NPT, supra note 19, at Art. IX.

95. Youngblood, supra note 6 , at 331.

96. Id.

97. NPT, supra note 19, at Art. I. 
manufacture of nuclear weapons or other nuclear explosive devices. ${ }^{98}$

"The benefits of the nuclear power technology coupled with the international respect of membership, make the NPT hard to resist for a country desiring nuclear power." 99

The difficulty inherent in producing nuclear weapons is germane to proliferation control. Each signator to the NPT must "agree to be bound by [the treaty's] terms in order to receive the technology needed to support a successful nuclear power program."100 Since an essential purpose of the NPT is to assist, or even encourage, the development of nuclear energy capabilities while severely restricting access to nuclear weapons technology, ${ }^{101}$ the NPT encourages the dissemination of technology which could indirectly increase a state's capacity to produce nuclear bombs. ${ }^{102}$

In ratifying the NPT, the non-nuclear weapon states pledged not to secure, manufacture, or otherwise acquire a nuclear arsenal. They also committed themselves to accept safeguards as set forth in an agreement with the International Atomic Energy Agency (IAEA) ${ }^{103}$ regarding all fissionable material used in peaceful nuclear activities within their territory or jurisdiction. ${ }^{104}$ The non-proliferation commitment of the NPT and the acceptance of comprehensive safeguards on all peaceful nuclear activities attempted to address the political and security concerns of nuclear proliferation. ${ }^{105}$

In order to prevent diversion of fissile material to non-nuclear weapons states, fissile material must be accounted for. ${ }^{106}$ Article III of the NPT requires each signatory nation to negotiate safeguard covenants ${ }^{107}$ with the IAEA overseeing all of their peaceful nuclear activities. ${ }^{108}$ The safeguards that the nonnuclear states must accept are not specifically addressed by the NPT itself, rather each country must individually work out the safeguard details with the IAEA. ${ }^{109}$ Even though the NPT does not require that safeguards be applied to nuclear

98. Id at Art. II.

99. Youngblood, supra note 6, at 336.

100. Youngblood, supra note 6, at 335-336; see NPT, supra note 19, at Art. I

101. See generally Brian J. Leslie, Note, Dual Use Goods and the European Community: Problems and Prospects in Eliminating Internal Border Controls on Sensitive Products, 17 B.C. INT'L \& COMP. L. REV. 193 (1994).

102. NPT, supra note 19, at Art. IV. "All the Parties to the Treaty undertake to facilitate, and have the right to participate in, the fullest possible exchange of equipment, materials and scientific and technological information for the peaceful uses of nuclear energy." Id.

103. See infra text accompanying notes 123 to 160.

104. NPT, supra note 19, at Art. III, $\$ 1$.

105. SCHEINMAN, supra note 14 , at 148.

106. John H. Nuckolls, Post-Cold War Nuclear Dangers: Proliferation and Terrorism, Science, Feb. 24, 1995, available in LEXIS, Nexis Library, ASAPI File.

107. NPT, supra note 19, at Art. III.

108. Id.

109. Id. 
activities in the nuclear weapon states, ${ }^{110}$ all five have volunteered to place their nuclear activities under IAEA safeguards. ${ }^{11}$

The safeguards are supposed to timely detect "diversion of significant quantities of nuclear material from peaceful activities to the manufacture of nuclear weapons." 112 Safeguards also engender confidence in the nature of each state's nuclear activity and expedite international cooperation in the development of nuclear energy. ${ }^{113}$ For material existing within a country, the safeguarding procedure comprises three basic factors: (1) cataloging every transfer into or out of fissile material storage facilities such that the IAEA and the state are informed at all times of the quantity, locality, and movement of nuclear commodities; ${ }^{114}$ (2) installation of containment and surveillance devices at the fissile storage facilities; ${ }^{115}$ and (3) human observation of the facilities. ${ }^{116}$ Unfortunately, these safeguards apply to declared nuclear material and not to the transfer or receipt of undeclared nuclear weapons or devices. Nor are the safeguards intended to verify that a state is not making preparations for developing a nuclear explosive device. ${ }^{117}$

The enforcement mechanisms available to stop the supply of nuclear expertise, ranging from the efforts of Russia to stop the unlawful emigration of its scientists to the role of the international community in deterring and prosecuting these scientists, differ from the mechanisms used to stop the demand for nuclear weapons. Article I of the NPT fails to address the problem of nuclearexpertise proliferation. The fact that Russian nationals are lending aid to another state's nuclear weapons program is probably not a technical violation of the NPT because there is no state action involved (i.e., Russia ${ }^{118}$ is not assisting,

110. Id.

111. See Michael J. Wilmshurst, The Adequacy of IAEA Safeguards for the 1990's, in NUClEAR NON-PROLIFERATION AND THE NON-PROLIFERATION TREATY, at 13.

112. Jozef Goldblat, The Non-Proliferation Treaty: How to Remove the Residual Threats, UNIDR, United Nations Institute for Disarmament Research 6 (1992).

113. SCHEINMAN, supra note 14 , at 168.

114. 1 NUCLEAR ENERGY AGENCY, ORGANIZATION FOR ECONOMIC COOPERATION AND DEVELOPMENT, THE REGULATION OF NUCLEAR TRADE 53 (1988).

115. Id at 54.

116. Id.

117. SCHEINMAN, supra note 14 , at 168.

118. See generally Edwin D. Williamson \& John E. Osborn, A U.S. Perspective on Treaty Succession and Related Issues in the Wake of the Breakup of the USSR and Yugoslavia, 33 VA. J. INT'L L. 261 (1993).

The former Soviet Union was the signor to the NPT in 1970. Since this time the Soviet Union has split up into various republics and states. This break up left a vacuum in regards to the treaties that the Soviet Union had entered into. Accordingly, with the Alma Ata Declaration, the republics of the former Soviet Union guaranteed the 'fulfillment of intemational obligations stemming from the treaties and agreements of the former U.S.S.R."

Id. quoting Text of Alma Alta Declaration: Mutual Recognition and An Ernest Basis, N.Y TIMES, 
encouraging, or inducing any action because it is not sending its scientist abroad). Rather, these scientists are voluntarily leaving Russia against the interests and desires of the Russian government. Under the NPT, the Russian government is not compelled to prohibit its people from emigrating.

"Prior to the discovery of the Iraqi and Northern Korean nuclear programs no material breaches of the NPT had been recorded."119 Subsequently, however, the insufficiencies of the treaty have become prominent. Parties to the treaty observe the provisions as they see fit, they could conceivably claim acquiescence to the NPT yet covertly seek to distribute fissile material. Iraq proclaimed obeisance to the NPT prior to the Gulf War, North Korea overtly refuses to comply with mandatory inspections. Meanwhile, states outside the NPT like Israel, a nuclear weapons nation, ${ }^{120}$ and in the past South Africa, ${ }^{121}$ refuse to enter the treaty while other non-nuclear states remain legally unobstructed in their pursuit of nuclear activities. ${ }^{122}$ Even though Article II explicitly outlaws solicitation efforts by non-nuclear countries, ${ }^{123}$ the treaty's safeguards are too weak to enforce its mandates, especially in the face of intense demand for nuclear expertise.

\section{THE INTERNATIONAL ATOMIC ENERGY AGENCY}

After World War II, the initial United States response to the apocalyptic hazards of atomic weaponry was to enact the Atomic Energy Act. ${ }^{124}$ This act

Dec. 22, 1991, at A12. The problem is that under the NPT there were only five countries authorized to maintain nuclear weapons and the Soviet Union was one of these. Accordingly the U.S. argued that Russia should continue to not only occupy both the former Soviet Union's General Assembly and Security Council Seats but also the other republics must apply for membership into the United Nations as new states. One of the arguments for this was that Russia is clearly the dominant part of the former Soviet Union and this falls in line with eleven of the former Soviet republics that Russia be given the USSR Security Council seat. Id. at 264-265.

119. Kellman, supra note 3 , at 801 .

120. Israel is believed to have as many as 100 nuclear weapons. Global View, supra note 19.

121. Goldblat, supra note 112 , at 2 . South Africa formerly maintained nuclear weapons, however, it dismantled its arsenal in compliance with the NPT. Id.

122. Id

123. NPT, supra note 19, at Art. II.

124. Atomic Energy Act of 1946, Pub. L. No. 79-585, 60 Stat. 755 (1946). "The first attempts to control nuclear weapons were made immediately after the first bombs were used. The most important of the early steps was the so-called Baruch Plan, named after Bernard Baruch, who presented it on behalf of the United States to the United Nations in 1946." "[T] he plan was .. . 'too radical ....' In particular it called for intrusions on sovereignty that were totally unacoeptable to the Soviets, then under the rule of Stalin, and (probably unacceptable to) the US Senate ... if such an agreement had been put before it for ratification in those times." Herbert $F$. York, The CTBT and Beyond, UNIDIR, UNITED NATIONS INSTITUTE FOR DISARMAMENT RESEARCH, 1 (1994). 
attempted to contain the spread of nuclear technologies via secrecy and denial. The act prohibited "any person ... to (A) possess or transfer any fissionable material ..., or (B) export from or import into the United States any fissionable material, or (C) directly or indirectly engage in the production of any fissionable material outside of the United States." 125 The effectiveness of this act quickly dissipated as countries successfully tested their atomic weapons. ${ }^{126}$

On December 8, 1953, to ameliorate the ineffective Act President Dwight D. Eisenhower proffered, what was latter termed, the "Atoms for Peace" plan to the United Nations (U.N.) General Assembly. ${ }^{127}$ He proposed setting up an Atomic Energy Agency under the aegis of the U.N. which would be responsible for the impounding, storage, and protection of contributed fissionable materials. ${ }^{128}$ In addition, the "responsibility of this Atomic Energy Agency would be to devise methods whereby this fissionable material would be allocated to serve the peaceful pursuits of mankind." 129 Eisenhower believed that "[i]t is not enough to take this weapon out of the hands of the soldiers. It must be put into the hands of those who will know how to strip its military casing and adapt it to the arts of peace." 130 Finally, in order for this proposal to be effective, Eisenhower requested that involved governments contribute portions of their fissionable material stockpiles to the Agency. ${ }^{131}$

This Atoms for Peace proposal effectively rejected earlier and more encyclopedic strategies, acknowledging that comprehensive international control over nuclear weaponry would be formidable. By proposing such a plan, Eisenhower wished to strengthen and amplify American military and economic ties around the world, assure American primacy in international nuclear councils, advance American power reactor sales, yet concomitantly promote disarmament. ${ }^{132}$

As a result, on July 29,1957 , the U.N. established the International Atomic Energy Agency (IAEA) ${ }^{133}$ to "accelerate and enlarge the contribution of atomic energy to peace, health and prosperity throughout the world." 134 The IAEA was

125. Atomic Energy Act, supra note $124, \$ 5(\mathrm{a})(3)$.

126. Two of the earliest successful tests were conducted by the Soviet Union in 1949 and Great Britain in 1952. See SCHEINMAN, supra note 14, at 17.

127. Dwight D. Eisenhower, Peaceful Uses of Atomic Energy, Address Before the General Assembly of the United Nations, (Dec. 8, 1953) in PUblic PAPERS OF THE PREsidents, at $813-$ 822.

128. Id. at 821 .

129. Id. "A special purpose would be to provide abundant electrical energy in the powerstarved areas of the world." Id.

130. Id. at 820 .

131. Id.

132. SCHEINMAN, supra note 14 , at 62 .

133. Id. at 74.

134. Statute of the International Atomic Energy Agency, Oct. 26, 1956, art. I, 8 U.S.T. 1093, 276 U.N.T.S. 3. 
authorized to "establish and administer safeguards designed to ensure that special fissionable and other materials, services, equipment, facilities and information made available by the Agency or at its request or under its supervision or control [were] not used in such a way as to further any military purpose."135 In addition, the IAEA was empowered:

To send into the territory of the recipient State or States inspectors ... hav[ing] access at all times to all places and data and to any person who by reason of his occupation deals with materials, equipment, or facilities which are required by this Statute to be safeguarded ... and to determine whether there is compliance with the undertaking against use in furtherance of any military purpose . 136

Since 1970, IAEA responsibilities result primarily from non-nuclear weapon states joining the NPT and obligating themselves to accept IAEA safeguards on all their nuclear activities. ${ }^{137}$ Unfortunately, the safeguards are neither intended to seek out clandestine operations nor undeclared activities, nor govern or regulate national action. Their function is to monitor, audit and report in order to verify that states are in compliance with their voluntary undertakings. ${ }^{138}$ IAEA members do not have to submit to safeguards unless the member has sought and received assistance in some peaceful nuclear activity from the agency. In fact, nuclear safety is ultimately a national responsibility, and only the state has the authority to legislate and enforce. ${ }^{139}$ Consequently, some fissile material activity will go undetected.

The IAEA abandoned the idea of monopolizing fissile material in favor of a system of international verification of nationally owned and controlled nuclear activities by member states. ${ }^{140}$ In recognizing that the logistics of a fissile material monopoly were problematic, the U.N. has adopted a system of voluntary compliance. By volunteering to conform with the NPT, each state subjects itself to verification that its international nuclear commitments are not breached. Preventing the unauthorized accumulation of fissionable material is believed to be more successful if the material is discovered during the early stages of weapons fabrication rather than in the later stages (such as an actual bomb). ${ }^{141}$

The IAEA's effectiveness has been restrained due to its limited datagathering operations. Often the Agency must solicit intelligence about a

135. Id. at Art. III, A.5.

136. Id at Art. XII, A.6.

137. SCHEINMAN, supra note 14 , at 125.

138. Id.

139. Id. at 103.

140. Id.

141. Id. at $122-23$ 
particular country's nuclear activities from outside intelligence agencies. ${ }^{142}$ Fol example, Hans Friedrich Meyer, a spokesperson for the IAEA, claims that unti. the agency has independent confirmation from some reputable institution, it mus remain aloof of reports that Saudi Arabia, Iran, Iraq, Turkey and Pakistan have visited Dushanbe, the capital of Kazakhstan, and shopped for nuclear technology. ${ }^{143}$

The IAEA acknowledges the inhering risks associated with its present restrictions; consequently, the agency has requested greater autonomy in monitoring potential trafficking in nuclear materials. ${ }^{14}$ IAEA experts state that the risk of smuggling and leakage depends on the reliability of the CIS's system of accounting for its nuclear weapons. This system is weakest when weapons are being transported. ${ }^{145}$ To effectively ameliorate the deficiencies in the current CIS monitoring systems, the IAEA should be given control over the entire nuclear cycle, from the mining of uranium and the production of deuterium and tritium to the handling of waste; however, the feasibility of this type of monitoring system may be fiscally unreasonable. ${ }^{146}$

In addition to expanding the powers of the IAEA, the fiscal quandary must be overcome. The present finite financial budget of the agency effectively renders meaningful inspection impossible. ${ }^{147}$ As a result, the agency rarely exercises its full power of inspection; hence, much has slipped through the Agency's fingers. The Iraqi's clandestine buildup of nuclear technology amplifies this dilemma. Prior to the Gulf War, the agency's inspections dis-covered no illegitimate nuclear activities; the Iraqi nuclear technology was allegedly for peaceful use only. ${ }^{148}$ In fact, Iraq had been a member of the NPT and the IAEA for the previous ten years during which they took an active role in fostering nonproliferation and peaceful nuclear cooperation. ${ }^{149}$ Prior to its invasion of Kuwait, many experts believed that, Iraq was five to ten years away from developing a viable nuclear arsenal. ${ }^{150}$ As subsequent events demonstrated, the time frame, and scale of Iraqi nuclear activity was grossly underestimated. This Iraqi nuclear deception emphasizes the inadequacies of both the NPT and the IAEA.

142. Peter Beaumont, Austria: West Gets Tough on Plutonium Trade, OBSERVER, Sept. 18, 1994, available in WESTLAW, NT-NEWS File [hereinafter Trade].

143. LAEA Seeks Tougher Nuclear Checks in Response to Collapse of Soviet Union, AGENCE FraNCE PRESSE, Jan. 3, 1992, available in LEXIS, Nexis Library, AFT File.

144. Id.

145. Levin, supra note 62 , at 975 .

146. North Korea and Iraq criticized at IAEA meeting, DEUTSCHE PRESSE-AGENTUR, Sept. 22, 1995; Secretary's Statement on International Day of Peace, FEDERAL NEws SERVICE, Sept. $20,1995$.

147. Id.

148. Global View, supra note 19. Their secret program was housed at the same facility as was safeguarded and inspected twice a year by the IAEA. Id.

149. Id.

150. Id. 
In an attempt to mitigate fears of nuclear proliferation, the IAEA claims that would-be nuclear powers would have great difficulty servicing a plutoniumbased weapon. ${ }^{151}$ Plutonium-based warheads are relatively insatiable, thus requiring careful maintenance and having a short shelf-life compared to other conventional weapons. Maurizio Zifferero of the IAEA said that plutonium 241 isotope, which accompanies plutonium 239 , decays and causes contamination that would require the warhead to be regularly cleaned by a large and steady flow of plutonium. ${ }^{152}$ A single warhead with the minimum amount of plutonium, about five kilograms, has a shelf-life of between one and two years during which it must be carefully serviced. If the plutonium was not pure but only 80 percent enriched, then perhaps twice as much plutonium would be necessary for servicing. If the state wished to ensure a nuclear threat, a steady flow of the material would be necessary to help with the sophisticated reprocessing requirements. ${ }^{153}$ Consequently, nuclear powers like the United States and Britain regularly rotate the warheads in order to ensure their serviceability. ${ }^{154}$ Due to the inherent difficulties in developing a plutonium based weapon, "it does not make a great deal of sense to be buying plutonium unless you have had a previous program, and even then it would be easier to use a uranium-based weapon, which you can machine and weaponise in the open."15s Countries like Iraq that have spent considerable money and expertise on a simpler uranium-based weapons system have had enomous trouble servicing this system. ${ }^{156}$

Presently, international supervision over the world's estimated supply of 1,000 tons of plutonium and 1,500 tons of Highly Enriched Uranium (HEU) is woefully limited. ${ }^{157}$ Approximately $95 \%$ of the HEU inventories are controlled by the United States and Russian armed forces. Only 1\% of the world's HEU is under the safeguards administered by the IAEA. Plutonium, meanwhile, is mostly under the auspices of civilian control, falling under international safeguards. ${ }^{158}$

Due to the recent concern over the smuggling of fissile material, there has been an outcry for the strengthening of the IAEA. Great Britain, the United States, France, and Germany have asked that the Agency's duties be expanded to become an intelligence clearing house in the fight against smugglers. ${ }^{159}$ In an effort to facilitate this purpose, the above four countries have pledged to provide

151. Peter Beaumont, Germany: Only Big Boys Need Apply-Plutonium, OBSERVER, Aug. 21, 1994, available in WESTLAW, INT-NEWS FILE.

152. Id.

153. Id

154. Id.

155. Id.

156. Id.

157. Plutonium, supra note 15 , at 99.

158. Id.

159. Trade, supra note 142 . 
up to 6.4 million dollars. ${ }^{160}$ Additionally, IAEA directors have proposed setting up an international database to track plutonium smugglers, and the U.S. National Security Council has promised to pay for this database. ${ }^{161}$ The IAEA also is considering how to "set up a series of international missions-similar to its established nuclear safety inspectorates- to inspect plutonium-handling facilities and to provide expertise and hardware." 162

Nevertheless, the IAEA is the appropriate agency to monitor the disposition of CIS nuclear technology and its possible transferal to third world powers. As most of these countries are signatories of the NPT, it is within the jurisdiction of the IAEA to inspect all nuclear technology in the possession of these countries to determine whether it is being used for peaceful purposes. In theory, the IAEA has the right to review all documents and records, send inspectors into safeguarded states, have access at all times and places, as necessary, to account for the materials, and determine whether their country is in compliance with the NPT. ${ }^{163}$ In practice, however, this is not always the case.

\section{Policing Mechanisms in Place}

Policemen depend upon the powers conferred by the state to perform many of their criminal investigative functions, yet the internationalization of their investigations thrusts them beyond the jurisdiction of their sovereign, where they are effectively stripped of their police powers. The result is that most international law enforcement activities must depend upon the cooperation of foreign authorities. ${ }^{164}$

\section{A. Interpol}

The International Criminal Police Organization (Interpol) ${ }^{165}$ was formed in 1923. Although World War II briefly interrupted its existence, Interpol has continued to prosper and now has over 140 member countries. ${ }^{166}$ Headquartered in St. Cloud, France, Interpol promotes mutual assistance among criminal police

160. Id.

161. Id.

162. Id.

163. SCHEINMAN, supra note 14 , at 125.

164. Detlev F. Vagts \& Ethan A. Nadelmann, Policing the World: Interpol and the Politics of Intemational Police, 85 AM J. INT'L L. 426, 426 (1991) (reviewing MALCOM ANDERSON, COOPERATION (1989)).

165. See generally PETER G. LEE, INTERPOL (1976). In 1938, Congress empowered the Attorney General to accept Interpol membership for the United States. See 22 U.S.C. \$ 26.3(a) (1995).

166. See Lee, supra note 165. 
authorities in an attempt to better coordinate crime prevention. ${ }^{167}$ Primarily a criminal information exchange service, Interpol serves as a central repository for the collection, transmission, and analysis of information on transnational criminals. ${ }^{168}$

A nation's reliance on Interpol tends to be in proportion to the extent the nation must cope with international crime and the quality of its law enforcement division's relationship with its foreign counterparts. In contrast, in many less developed states, police agencies rely on Interpol out of necessity. ${ }^{169}$ In developed areas, such as Western Europe, bilateral relations among the national police agencies are well-developed. ${ }^{170}$ Many of these law enforcement agencies are frustrated with Interpol due to its failure to adapt to changing circumstances and to quickly integrate new technological advances in crime control and communications. ${ }^{171}$

Despite the steady rise in international police cooperation, there is not a single international convention which governs or regulates interstate cooperation among police agencies. ${ }^{172}$ Interpol has limited jurisdiction and authority in the areas of international law enforcement since it usually operates on a voluntary basis in agreements between domestic police agencies. The rise in drug trafficking, organized crime, and terrorism has resulted in a higher interaction between Interpol and national police agencies. ${ }^{173}$ Unfortunately such cooperation has been relegated to bilateral and informal arrangements which do not have the status of treaties.

\section{B. Europol}

In Maastricht, Netherlands in December of 1991 the Treaty on the European Union ${ }^{174}$ was signed by the twelve members of the European Community $(E C) .{ }^{175}$ The treaty's underlying purpose is to enable the EC "to play a more coherent political and economic role in the world, commensurate with its

167. See Id.

168. See Ethan A. Nadelmann, The Role of the U.S. in International Enforcement of Criminal Law, 31 HARV. INT'L L. J. 37, 46 (1990).

169. Id.

170. Id.

171. Fijnaut, The Internationalization of Criminal Investigation In Western Europe, in POLICE COOPERATION IN EUROPE 32, 37-42 (C. Fijnault \& R.H. Hermans Eds., 1987).

172. See M. Cherif Bassiouni, Policy Considerations on Inter-State Cooperation in Criminal Matters, 4 PACE Y.B. INT'L L. 123, (1992).

173. Mary J. Grotenroth, Interpol's Role in Intemational Law Enforcement, in LEGAL RESPONSES TO INTERNATIONAL TERRORISM: U.S. PROCEDURAL ASPECTS 375-76 (M. Cherif Bassiouni ed., 1988).

174. Maastricht Treaty on the European Union, Feb. 7, 1992, 31 I.L.M. 247.

175. Id. The twelve states include: Belgium, Denmark, France, Germany, Greece, Ireland, Italy, Luxembourg, The Netherlands, Portugal, Spain and the United Kingdom. Id. 
international responsibilities." 176 This treaty, wider in scope than any previous EC treaty, consists of three pillars. The Third or Judicial and Internal Affairs Pillar covers a substantial range of issues including the creation of a unionwide police information exchange system, Europol. ${ }^{177}$ The European Council ${ }^{178}$ agreed to create Europol in order to organize the exchange of information between the EC police and customs agencies ${ }^{179}$ in the fight against drugs within the EC's twelve member states. ${ }^{180}$ Headquartered in the Hague, Europol's responsibilities have been expanded to include combating illegal immigration, car theft, and the smuggling of fissile material. ${ }^{181}$

With the termination of the Cold War and the fall of the Iron Curtain, criminal organizations have become increasingly sophisticated. ${ }^{182}$ This, coupled with the European Unions' lack of cohesion, ${ }^{183}$ has enabled criminals to traverse the continent without trepidation. ${ }^{184}$

Mired in technological, legal and political hang-ups, ${ }^{185}$ Europol has yet to be accepted as a viable alternative to national police forces and Interpol. ${ }^{186} \mathrm{EC}$ members disagree on how much autonomy Europol should receive over traditional national matters. Indeed, most member states are against Europol becoming the primary crime fighting mechanism within the EC due to national

176. New European Treaty is Signed in Maastricht, PRNEWSWIRE, Feb. 7, 1992, available in WESTLAW, PRNEWS File (press release by the European Commission) [hereinafter Treaty].

177. Id.

178. Four institutions comprise the European Community: the Council of Ministers, the Commission, the Parliament, and the Court of Justice. The Commission and the Council work together to create legislation. The Commission initiates legislative proposals and the Council effectuates enactments subject to review and recommendations of Parliament. The Court of Justice interprets and enforces application of EC law. See generally David O'Keefe, Current Issues in European Integration, 7 PACE INT'L L. REV. 1, 3 (1995).

179. Stephen Nisbet, EU Seeks Tougher Action on Drugs, Nuclear Trade, REUTERs, Sept. 5, 1994, available in LEXIS, Nexis Library, International File.

180. Treaty, supra note 176.

181. Alister Bull, Europol Strains at Leash as Politicians Wrangle, REUTERs EUROPEAN COMMUNITY REPORT, Jan. 9, 1995, available in LEXIS, Nexis Library, International File.

182. Tyler Marshall, European Nations Combine to Combat Crime, LOS ANGELES TIMES, Sept. 9, 1994, available in LEXIS, Nex is Library, PAPERSMJ File.

183. Major difficulties in the EC include legal, bureaucratic, and language differences.

184. Marcus Kabel, German Business Fears Organized Crime Stranglehold, REUTERs, Sept. 22. 1994, available in LEXIS, Nexis Library, International File.

185. See French Officials Outline Four-Point Presidency Plan, REUTERs, Jan. 9, 1995, available in LEXIS, Nexis, Intemational File. In 1994, no central data base had been set up and the reluctance of France and Great Britain to pass on information to Europol on the grounds of national sovereignty have slowed the progress of Europol. Id.

186. Bull, supra note 181 . The problem with Interpol is that it has world wide jurisdiction. It is not able to focus sufficient means in order to combat many of the criminal activities in Europe. Id. 
sovereignty issues. ${ }^{187}$ Germany, however, wants Europol strengthened to address the new wave of organized crime, especially since it is vulnerable to criminal activities along a weakened Polish border. ${ }^{188}$ Europol is indispensable in filling the enforcement vacuum: Interactive information and communication systems could expeditiously coordinate the fight against international gangs which easily circumvent present national police agencies handcuffed by jurisdictional limitations. ${ }^{189}$ Each member state must set up interactive communication systems in order to ensure rapid response to the criminal's activities.

\section{RECOMMENDATIONS}

The proliferation of fissile material must be promptly addressed. With the increasingly frequent reports of nuclear smuggling, eventually enough nuclear material will wind up in the possession of terrorists or religious fanatics. "Although the cases of smuggling plutonium discovered to date in Germany and Eastern Europe have involved relatively small quantities of fissile materials, the capture of this material should provide only a modicum of reassurance-the smugglers who have been apprehended may be the clumsiest or most careless, or those most likely to fall for sting operations run by police and journalists."190 Russia lacks sufficient funds and political stability to properly deal with its nuclear weapons, hence the EC along with the U.S. must lend financial assistance in order to set up proper control mechanisms. The present conversion program, an attempt to convert many of the weapons producing industries into other enterprises, must continue to receive EC and U.S. support.

\section{A. Comprehensive Test Ban Treaty}

A comprehensive $\operatorname{ban}^{191}$ on testing nuclear weapons will not preclude the

187. Europe is Failing to Curb Drug Trade, The Dally Telegraph, Sept. 9, 1994, available in LEXIS, Nexis Library, International File.

188. Nisbet, supra note 179.

189. Bull, supra note 181.

190. Albright, supra note 1.

191. "In 1958 both President Eisenhower and Chairman Khrushcev undertook the first serious negotiations designed to achieve a comprehensive ban on nuclear weapons testing." President Eisenhower had two major goals in pursuing such a treaty. First, he wished to take a "decisive, though modest, first step down the long road leading to the eventual elimination of the nuclear threat." There had previously been many unsuccessful proposals seeking to control the nuclear threat.

The second purpose for the CTBT was to open the Soviet Union to outsiders. Eisenhower recognized that a CTBT would necessitate "some sort of international observation and inspection system." Since at that time the Soviet Union was relatively closed to all foreigners, any type of opening in the Iron Curtain would be useful for United States security interests. 
smuggling of fissile material. That all the nuclear powers would agree, with the present state of the world, to such a ban is not reasonable. ${ }^{192}$ A Comprehensive Test Ban Treaty (CTBT) cannot by itself prevent the acquisition of nuclear weapons by non-nuclear states. Even if such a ban were implemented, terrorists and rogue states could still procure nuclear weapons. ${ }^{193}$ A CTBT may have been effective if implemented in the 1950s and 1960s when the technology was relatively new and each nation had a few highly skilled scientists developing (and testing) nuclear weapons. But, as nuclear weapons technology has became more mainstream, less testing of nuclear weapons is necessary. Powerful, concise nuclear weapons, weighing much less than the Hiroshima bomb, can easily be designed and built without testing. ${ }^{194}$

In addition, France and Great Britain are in a significantly different position than the United States and Russia in regards to nuclear weapons. ${ }^{195}$ Both European countries have a more modest arsenal and much smaller quantities of fissile material than the United States and Russia. ${ }^{196}$ "They must therefore see to the preservation of other basic interests."197 Countries free from potential regional conflicts are less likely to be concerned with maintaining a nuclear arsenal. ${ }^{198}$ However, countries with real or perceived threats to their security will insist on testing their nuclear arsenal. For example, French President Jacques

"In the meantime, in the mid 1960 's, after the first five states had already tested and deployed nuclear weapons, negotiations on" the NPT were well underway. With article six of the NPT, each of the parties is called upon "to pursue negotiations in good faith on effective measures relating to cessation of the nuclear arms race at an early date and to nuclear disarmament ... under effective international control." "The preamble of the treaty and the negotiating record make it abundantly clear that a comprehensive test ban was widely considered to be an essential part of the" process of nuclear disarmament. A CTBT had in effect become a "part of the promise the states that had nuclear weapons made to the states that did not have them in order to persuade them to forever forego the acquisition of such weapons for themselves." Consequently, many feel that fulfillment of the promise by the five nuclear weapon powers to enter into a CTBT is overdue. Herbert F. York, The CTBT and Beyond, UNIDIR, UNITED NATIONS INSTITUTE FOR DISARMAMENT RESEARCH, 2 (1994).

192. For example, France has tested nuclear weapons after the NPT was renewed in April 1995. See Robert K Musil \& Daryl G. Kimbal, France Is Testing Patience of World, NEWSDAY, Oct. 24, 1995, at A35, available in LEXIS, Nexis Library, NEWSDY File.

193. York, supra note 191, at 4.

194. Id. THE reality of building nuclear weapons without extensive testing is demonstrated by Pakistan, Isreal, and South Africa. All of them have designed and built nuclear weapons without prior testing. Id at 5 .

195. Therese Delpech, A Convention on the Prohibition of the Production of Fissile Material: Uncerain Benefits for Non-Proliferation, in Halting the Production of Fissile Materials for Nuclear Weapons, UNDIR, United Nations for Disarmament Research (1994).

196. Id

197. Id

198. Sedavid Fischer, Drawing the Threshold States into a Regime of Restraint by Joining the NPT or Otherwise, in NUCLAR NON-PROLIFERATION AND THE NON-PROLIFERATION TREATY 36, 39 (Michael P. Fry et al. eds., 1989). 
Chirac claims that maintenance of his country's nuclear arsenal is necessary for security interests. ${ }^{199}$

\section{B. Domestic Legislation}

Assisting another state or group to develop nuclear weapons must be criminalized through domestic legislation, ${ }^{200}$ strong disincentives must be developed in order to prevent scientists from becoming nuclear mercenaries. The CIA believes the potential emigration of former Soviet scientists to aid rogue states in their development of nuclear weapons to be the most obdurate nuclear proliferation problem. ${ }^{201}$ To curtail this problem, the U.S. Congress found it within the "national security interest of the United States ... to facilitate, on a priority basis . .. the prevention or diversion of weapons-related scientific expertise of the former Soviet Union to terrorist groups or third countries." ${ }^{202}$

Russia and the CIS must enact and enforce similar legislation. Restraints must be sufficient so as to effectively offer adequate incentives to the scientist to remain at home; the economic hardship in Russia must be eased. The U.S. State Department recognizes the financial quagmire of nuclear physicists and has offered to provide funds to help those scientists work in peaceful applications of their knowledge and expertise. ${ }^{203}$ This would deter many scientists from becoming involved in the development of other nations' nuclear capacities.

\section{C. $N P T$}

The NPT should be amended to discourage nuclear-expertise proliferation. The idea that Russian nationals technically may lend aid to another state's nuclear weapons program is a reprehensible oversight. The insertion of laws prohibiting "citizens of one country from participating in another state's nuclear weapon program"204 or citizen participation laws into the NPT could help curtail the

199. Musil, supra note 192. Frances nuclear weapons arsenal has not been effective in preventing terrorists attacks within its borders. See Id.

200. For example, the U.S. has enacted several statutes prohibiting the assistance to another country in the development of their nuclear arsenal. See 42 U.S.C. $\$ 2277$ (1995); 50 U.S.C. \& 783 (b), (d) (Supp. 1995).

201. An example of the potential problem that could occur if nuclear experts are induced to join forces with termorists organizations is demonstrated by the Japanese Cult that used nerve gas in Japanese subways in March 1995. It was reported after the cult was broken up that efforts were being made to recruit Russians who had expertise in nuclear activities. Japanese Cult Recruited Nuclear Experts, Senator Says, Miami Herald, Oct. 16, 1995, at A4.

202. Former Soviet Union Demilitarization Act of 1992, 22 U.S.C.S. 5901 (1992).

203. McCurry, supra note 46.

204. Treiger, supra note 69, at 248. 
emigration of nuclear mercenaries. ${ }^{205}$ Amending such clauses into the NPT would not only be precedentially sound but unabashedly moral. Poignant to prosperity of this proposal is the inclusion of a proviso granting jurisdiction to all stateparties over any illegal expertise proliferation, regardless of where the actions occur. "For example, if a proliferating scientist is arrested while vacationing in Barbados, [it] could litigate and penalize the proliferator pursuant to the NPT's grant of jurisdictional authority."206

In addition, "[t]he pledge of the nuclear weapon states in Article VI of the [NPT] to pursue comprehensive disarmament negotiations in good faith can hardly be said to have been fulfilled."207 France and China have tested nuclear weapons irrespective of their good faith requirements under Article VI of the NPT. ${ }^{208}$ In April 1995, at the NPT extension conference, "France and the other nuclear states won the uneasy support of the non-nuclear states not to pursue their own nuclear arsenals."209 In return, France promised to "eventually eliminate their own stockpiles."210 France's decision to test nuclear weapons after their pledge demonstrates the weaknesses of the NPT and its enforcement mechanisms. The only realistic methods to influence France to abide by its pledge would be non-legal, political measures such as embargoes on French products. ${ }^{211}$

205. Id. For a more indepth discussion of the effectiveness of "citizen participation laws" see Adam Treiger, Note, Plugging the Russian Brain Drain: Criminalizing Nuclear Expertise Proliferation, 82 GEO L. J. 237. There, the author discusses the effectiveness of "citizen participation laws" in respect to nuclear experts vending their skills abroad.

Such laws have been enacted in previous treaties effectively limiting the proliferation of weapons of mass destruction. For example, the Biological Weapons Convention Treaty contains such a clause in article IV which reads:

Each State Party to this Convention shall, in accordance with its constitutional processes, take any necessary measures to prohibit and prevent the development, production, stockpiling, acquisition or retention of the agents, toxins, weapons, equipment and means of delivery ... within the territory of such State, under its jurisdiction or under its control .... .

Id. (quoting Convention on the Prohibition of Bacteriological (Biological) and Toxin Weapons, Apr. 10, 1972, art IV, 26 U.S.T. 583,588, 1015 U.N.T.S. 163, 167).

206. Id. at 248.

207. Ove Bring, The Non-Proliferation Regime-Stronger than the NPT, in NUCLEAR NONPROLIFERATION TREATY 31 (Michael P. Fry et al eds., 1989).

208. Musil, supra note 192.

209. Id.

210. Id.

211. See Id. 


\section{IAEA}

For the IAEA to become more effective its budget must be increased. ${ }^{212}$ Russia, the CIS, and EC member states should be encouraged to increase their voluntary contributions. Next, the Agency must take a proactive role in monitoring nuclear weapons at the source as well as in possible destination countries. Whether these weapons are being prepared for dismantlement, shipped from one former republic to another, stored or left in place, every weapon must be accounted for. In light of the fact that tactical weapons are extremely small in size, great in number, and spread throughout military bases in the former Soviet Union, accounting for them becomes extremely important. ${ }^{213}$

\section{E. Consolidation}

To help ameliorate the tremendous logistical difficulties presented to the IAEA by the sheer volume of fissile material located in the former Soviet Union, Russia should be strongly encouraged to consolidate its holdings into a few well secured facilities. Currently, more than a hundred such facilities exist in Russia. With the lack of sufficient control mechanisms in place in Russian and other CIS states, it has been estimated that a few hundred million dollars would be needed to bring the existing facilities housing fissile material to a "tolerable level of protection." 214 If there were not over a hundred such facilities but rather twentyfive facilities with protections greater than "tolerable" the IAEA would be better able to maintain inspections of the facilities and Russia would have to expend less.

\section{E. Europol}

The EC should proceed with its implementation of Europol. Interpol is limited in its effectiveness due to its world-wide jurisdiction, and is not equipped to handle the magnitude of criminal activity that permeates the EC. Europol, however, as an embryonic entity is capable of focusing on arresting the spread of fissile material smuggling before it develops into a profitable enterprise for criminal and terrorist organizations. The EC should have Europol work in conjunction with the IAEA in monitoring clandestine nuclear activities of its member states. Europol's assistance would indirectly benefit the EC and allow the IAEA to focus its efforts in the volatile former Soviet Union.

212. The CIS has been derelict in its payments to the IAEA; in 1991 it reneged in its payment of $\$ 20$ million.

213. See generally Allison, supra note 17; Carnahan, supra note 26; Hearings, supra note 21 (testimony of Dr. Cochran).

214. Hearings, supra note 21 (testimony of Dr. Holdren). 
Timely detection and enforcement would effectively restrict the proliferation of fissile material and expertise. The IAEA, EC, and the former Soviet Union must coordinate efforts to arrest the development of this horrific potentiality. Nuclear weapons are presently sparse among rogue states. The involved parties should attempt to maintain this status since no nation is immune to the effects of a nuclear holocaust. The destructive powers of the original atom bomb should not be disparaged, they should be revered. Indeed, the smuggling of fissile material is an embryonic phenomena with a terrifying future.

Jeffrey B. Fugal* 